\title{
Late Cretaceous Climate of the Indian Subcontinent
}

\author{
Vandana Prasad \\ Birbal Sahni Institute of Palaeosciences, Lucknow, India \\ Email: prasad.van@gmail.com
}

How to cite this paper: Prasad, V. (2019) Late Cretaceous Climate of the Indian Subcontinent. Open Journal of Geology, 9, 692-695.

https://doi.org/10.4236/ojg.2019.910077

Received: August 17, 2019

Accepted: September 22, 2019

Published: September 25, 2019

Copyright (c) 2019 by author(s) and Scientific Research Publishing Inc. This work is licensed under the Creative Commons Attribution International License (CC BY 4.0).

http://creativecommons.org/licenses/by/4.0/

\section{(c) (i) Open Access}

\begin{abstract}
The Deccan Volcanism during the Late Cretaceous was a globally significant geological event, coinciding with the Cretaceous-Paleogene Boundary. The magma outpouring occurred in three phases. The flora that got preserved during the first phase $(30 \mathrm{~N})$ was a mixed gymnosperm and angiosperm flora ranging from dry to moist forest vegetation. The second phase (29R) flora is mostly represented by pteridophytes and tropical to sub-tropical angiosperm plant families. The palynofloral records from the third phase $(29 \mathrm{~N})$ are mostly tropical angiosperms. This floral turn-over is driven by latitudinal shifting of the Indian plate from sub-tropical to tropical zone. It is surmised that the latitudinal shifting of Indian plate during the span of $4 \mathrm{Ma}$ during the Late Maastrichtian led to the development of new ecological conditions favoring successful dominance of angiosperms over gymnosperms.
\end{abstract}

\section{Keywords}

Deccan Volcanic Province (DVP), Pollen, Spores, Plant Mega Fossils, Paleoecology

\section{Introduction}

The late Cretaceous deposits of India preserves the most important Large Igneous Provinces in the world, covering an area of about $512,000 \mathrm{~km}^{2}$ in the western and central parts of India. The sediments associated with the Deccan Volcanic Province (DVP) are represented by the infratrappean (Lameta Formation) and intertrappean beds. The magmatic outpouring occurred in three main phases with $6 \%$ of the total Deccan volume in phase-1 (base C30n), $80 \%$ in phase- 2 (C29r), and 14\% in phase-3 (C29n) [1]. The duration of intermittent volcanic activity spanned about $4 \mathrm{Ma}$ across the Cretaceous-Tertiary boundary [2]. The palynofloral records from infra and intertrap deposits from most of the areas are 
poor due to lack of good preservation conditions. Globally, the Late Cretaceous time witnessed the radiation of angiosperm forming nine phytogeographic provinces [3], out of which three lie in India. However, the assessment of their spatial and temporal distribution is difficult due to the paucity of continuous fossil records. Poor preservation conditions hamper the establishment of biostratigraphy and paleoenvironmental reconstruction of DVP associated sediments. However, we attempt to summarize the available mega and micro plant fossil data to infer floral transition and palaeoecological reconstruction during the Late Cretaceous in central India.

\section{Palynofloral Assemblages}

The igneous basalt flow occurred in three phases. The sedimentary deposits within the first phase mostly comprised of pteridophytic spores and pollens of Gymnosperm families like, Araucareaceae, Podocarpaceae, Corystospermaceae, Cheirolepidaceae and Ginkgoaceae while the angiosperm plant families consist of monosulcate pollen of Arecaceae family. Aquilapollenites sp., an angiosperm pollen is an age marker and common pollen of Maastrichtian deposits. There are also few angiosperm tricolpate pollens of uncertain origin.

The second phase witnessed an increase in the angiosperm diversity along with the already existing forms of pteridophytes and gymnosperms. The angiosperm families which make their appearance in this phase are Asteraceae, Caryophylaceae, Normapolles Group pollens and few other pollens such as Scabrastephanocolpites spp., Scollardiaconferta, Triporopollenites cracentis of unknown affinity [4]. The megafloral record of this phase is richer in comparison to microfossil record and represented by Flacourtiaceae, Icacinaceae, Euphorbiaceae, Capparidaceae, Boraginaceae and Sapindaceae [5] [6]. There are very few records of the third phase deposits like, Lalitpur intertrappean of Uttar Pradesh, and Mumbai intertrappean deposits. The deposits at Lalitpur yielded poor pollen assemblage of Dandotiaspora spp., Spinizonocolpites echinatus, Matanomadhiasulcites sp. and Lakiapollis ovatus [7] while deposits at Mumbai are completely devoid of plant fossils [8].

\section{Paleoclimate Reconstruction}

The first $(30 \mathrm{~N})$ and second phase (29R) of basalt flow occurred during Maastrichtian and the third $(29 \mathrm{~N})$ and final phase marked its presence in Paleocene [1]. The second phase of extensive basalt flow of Deccan Traps comprises $80 \%$ of the total basalt flow that coincides with the Cretaceous-Paleogene Boundary (K-Pg). Fossil flora associated with the DVP consists of mega and micro fossil records of pteridophytes, gymnosperms and angiosperms. The pteridophytes mostly grew in waterlogged, swampy and marshy conditions. The gymnosperm fossils recovered from the DVP were from the Lameta Formation below the $30 \mathrm{~N}$ trap deposits. They mostly belonged to mixed ecological conditions from evergreen (Araucareaceae, Podocarpaceae, Corystospermaceae) to dry land vegeta- 
tion (Cheirolepidaceae). As far as angiosperms are concerned, the major part of the assemblage was covered by brackish mangrove Nypa and Aquilapollenites pollen. The other plant fossils from the intertrappean localities associated with the latest Maastrichtian and Danian sequences show dominance of subtropical-tropical angiosperm plant families (Flacourtiaceae, Icacinaceae, Euphorbiaceae, Capparidaceae, Boraginaceae and Sapindaceae, Malvaceae, Meliaceae, Annonaceae, Vitaceae) while some of the pollens belonging to the Asteraceae, Caryophylaceae suggest cool climatic conditions [9]. The transition from gymnosperm-dominated to angiosperm-rich palaeovegetation during Maastrichtian is a significant floral turnover and can be due to climatic changes as a result of shifting of the Indian plate from the subtropical to tropical zone.

\section{Acknowledgements}

I am thankful to Birbal Sahni Institute of Palaeosciences, Lucknow, India for facilities. This is a contribution to UNESCI-IUGS IGCP Project 679.

\section{Conflicts of Interest}

The author declares no conflicts of interest regarding the publication of this paper.

\section{References}

[1] Chenet, A.L., Courtillot, V., Fluteau, F., Gerard, M., Quidelleur, X., Khadri, S.F.R., Subbarao, K.V. and Thordarson, T. (2009) Determination of Rapid Deccan Eruptions across the Cretaceous-Tertiary Boundary Using Palaeomagnetic Secular Variation: 2. Constraints from Analysis of Eight New Sections and Synthesis for a 3500 $\mathrm{m}$ Thick Composite Section. Journal of Geophysical Research, 114, B06103. https://doi.org/10.1029/2008JB005644

[2] Jerram, D.A. and Widdowson, M. (2005) The Anatomy of Continental Flood Basalt Provinces: Geological Constraints on the Processes and Products of Flood Volcanism. Lithos, 79, 385-405. https://doi.org/10.1016/j.lithos.2004.09.009

[3] Vajda, V. and Bercovici, A. (2014) The Global Vegetation Pattern across the Cretaceous-Paleogene Mass Extinction Interval: A Template for Other Extinction Events. Global and Planetary Change, 122, 29-49. https://doi.org/10.1016/j.gloplacha.2014.07.014

[4] Samant, B. and Mohabey, D.M. (2014) Deccan Volcanic Eruptions and Their Impact on Flora: Palynological Evidence. Geological Society of America Special Papers, 505, 171-191. https://doi.org/10.1130/2014.2505(08)

[5] Bonde, S.D. and Biradar, N.V. (1981) On Two Palm Woods from the Deccan Intertrappean Beds of Dongargaon District, Chandrapur, Maharashtra (India). Journal of University of Poona, 54, 247-257.

[6] Kar, R.K., Mohabey, D.M. and Shrivastava, R. (2004) First Occurrence of Angiospermous (Dicot) Fossil Woods from the Lameta Formation (Maastrichtian), Maharashtra, India. Geophytology, 33, 21-27.

[7] Singh, R.S. and Kar, R. (2002) Paleocene Palynofossils from the Lalitpur Intertrappean Beds, Uttar Pradesh. Journal of the Geological Society of India, 60, 213-216. 
[8] Cripps, J.A., Widdowson, M., Spicer, R.A. and Jolley, D.W. (2005) Coastal Ecosystem Response to Late Stage Deccan Trap Volcanism: The Post K-T Boundary (Danian) Palynofacies of Mumbai (Bombay), West India. Paleogeography, Paleoclimatology, Paleoecology, 216, 303-332.

https://doi.org/10.1016/j.palaeo.2004.11.007

[9] Prasad, V., Farooqui, A., Murthy, S., Sarate, O.S. and Bajpai, S. (2018) Palynological Assemblage from the Deccan Volcanic Province, Central India Provides Insights into Early History of Angiosperms and the Terminal Cretaceous Palaeogeography of Peninsular India. Cretaceous Research, 86, 186-198.

https://doi.org/10.1016/j.cretres.2018.03.004 